\title{
INTERNALIZING THE CHARACTER OF DISCIPLINE IN INTEGRATED ISLAMIC SCHOOL STUDENTS
}

\begin{abstract}
Anita, Wuri Wuryandani
Мета дослідження - теоретично відстежити інтерналізацію характеру дисиипліни студентів ІІПШ (SekolahDasar Islam Terpadu/Інтегрованої Ісламської початкової школи) Integrated Islamic Primary School).

Це теоретичне дослідження витікає з широкого публічного зачікавлення ІІПШ. Це стало иікавим питанням. Деякі друковані видання пишуть, щзо ия зацікавленість базується на кількох причинах. Одна $з$ них - виховання характерів. Це виховання є узгодженим з Президентським указом No. 87 Th 2017, щуо стосується посилення виховання характеру. В ІІПШ виховання характеру здійснюється протягом довгого часу. Виховання характеру здійснюється в процесі інтерналіцації в ІІПШ середовищі, щзо інтерналізує характери в икільному середовищі. Висвітлений характер ие дисципліна. Інтерналізація характеру цієї дисципліни може бути реалізований у п'ятьох стадіях, поєднаних з індикаторами дисиипліни характеру.

Базуючись на обговоренні презентованих теоретичних досліджень, було зроблено висновок про те, щзо проиес інтерналізаџії характеру дисиипліни студентів в інтегрованій Ісламській початковій школі здійснюється на п'ятьох стадіях дисциплінарних характерів, розвинених у студентів ІІПШ

Ключові слова: виховання, інтерналізачџія характеру, інтерналізація дисципліни, Ісламська школа, ІІПШ, студент
\end{abstract}

\section{Introduction}

Education in Indonesia is experiencing rapid development [1]. Starting from the curriculum to educators who increasingly pay attention to its quality. In addition, private schools also emerged that helped enliven the development of the world of education. According to Saud \& Johnston [2], Professional human resources, adequate facilities, a supportive curriculum, and appropriate implementation become synergies in improving the quality of educatio.

Indonesian people are increasingly clever in choosing good educational institutions for their children [3]. Today, it is not new anymore that private schools are starting to attract many people. Examples are Kanesius Elementary School, SD (Sekolah Dasar/ Primary School) Muhammadiyah, Islamic Elementary School, Integrated Islamic Elementary School, Natural Elementary School, and International Elementary School. Each of these private schools has its own advantages. However, the community until now has a tendency to send their children to SDIT (Sekolah Dasar Islam Terpadu/ Integrated Islamic Primary School).

\section{Literature review}

Yulianto [4] explained that parents would choose schools provided by SDIT for Muslims. SDIT is the best choice for parents. The reason parents choose SDIT is not only to obtain good religious knowledge, but also to collect existing characters. Talk about parents

The thing that has been done by the community fully supports the Government's program, namely Presidential Regulation Number 87 of 2017 [5] concerning Character Education Strengthening (PPK).
Knowledge of religion and cultivation of character became the reason for parents sending their children to SDIT. This is in accordance with Presidential Regulation No. 87 of 2017 [5] that those responsible for strengthening character education (PPK) are families, educational units, and communities. In addition, it is also stated that the aim of strengthening character education is to build and equip students to become Indonesia's golden generation in 2045 with the spirit of Pancasila and character to face the dynamics of the future.

In KDP there are five characters, namely religious, nationalist, integrity, independence and mutual cooperation. Each of these characters is translated again into several special characters. For example, independent characters include the character of hard work, creative, disciplined, courageous, and learners.

Based on Presidential Regulation Number 87 of 2017 [5], it shows the importance of implementing strengthening character education in schools. In the city of Yogyakarta, there are several SDITs that have carried out the strengthening of character education.

\section{The aim and objectives of the study}

The aim of this study is to review theoretically the internalization of the character of discipline in SDIT students.

To accomplish the aim, the following tasks have been set to review theoretically: students

1. The internalization of the character in SDIT

2. The process of estlabishing discipline in SDIT students. 


\section{Material and methods}

\section{1. Character Internalization}

Internalization of character is the internalization of value towards a person [6]. Internalization of characters cannot happen by itself. Implementation of internalization requires good planning. According to Muhadjir [7]there are five stages of character internalization process, namely:

1) Receive Value

Someone accepts value through various methods, including listening, seeing, and reading books. Through the senses of the listener and sight, one acquires knowledge related to that value.

2) Responding to Value

Someone will give a response if they have gained knowledge about values. The response was caused by stimulation of the five senses. The thing that lies behind the size of a response is attitude, perception, and participation. A person can respond to the knowledge of values received in different ways.

Basically, there are three responses or responses, namely accepting, rejecting, and indifferent to the values raised by the five senses.

3) Give value

This stage is someone will give an assessment of the knowledge of values that he received with the five senses. The assessment will be used as a benchmark for selecting the value of the value he received.

4) Live value

At this stage, a person will appreciate the value received by the five senses into his mind and feel it seriously. Until growing awareness in him to do that value.

5) Apply value

The application of values is the final stage in the internalization process. This application will occur after passing through the value appreciation process. Someone will apply these values in daily life.

\section{2. Discipline Character}

Character discipline is an important thing that must be considered in order to foster a person's character. Armed with the character values of discipline will encourage the growth of other good character values.

Curvin \& Mindler [8] mention three aspects of the discipline, namely:

1) Discipline to prevent problems;

2) Discipline to solve problems;

3) Discipline to overcome students who behave out of control.

Whereas according to Arikunto [9], the character of discipline has seven aspects, namely:

1) Doing schoolwork at home

If there are assignments from school or homework from the teacher, then students always do it at home. Both individually and in groups, and ask your mother's father if you experience difficulties.

2) Preparing for school needs at home

Students prepare all the necessities for school at home in the afternoon or evening. For example arranging books according to schedule, checking stationery, and preparing drinking bottles.

3) Attitudes of students in the class
During learning or ongoing teaching and learning activities, students pay close attention, carry out instructions seriously, and calm down or not make noise in the classroom. In addition, students also do assignments well in class.

4) Student attendance

Students always arrive on time or earlier when learning begins. Students never skip when learning takes place.

5) Carry out discipline at school

Students are used to leaving early before the bell rings to school. If students do not attend school, they will ask permission in writing, verbally, or in a message so the teacher knows it.

6) Everything related to lending and borrowing

Students will borrow a notebook from a friend if they feel the record is incomplete, then return it on time. Likewise, when borrowing books in the library, students will return and extend the book on time.

7) Take advantage of the time

Students get used to making a learning schedule or plan in order to study regularly. If students are at leisure, they will use it to study, read, write, or do other things that are addictive and produce.

The opinions above are synthesized, so that the aspects of the discipline character are seven, namely:

1) doing homework at home;

2) preparing for school needs tomorrow in the afternoon or evening at home;

3) keep the class conducive when the chase begins with oneself;

4) entering class before KBM starts;

5) implementing school discipline;

6) borrow and return on time;

7) make good use of time.

\section{3. Characteristics of Elementary Students}

Characteristics of elementary students are special and unique characteristics inherent in an elementary student. According to Hiroyuki, et.al [6], student characteristics are aspects or qualities of individual students such as talent, motivation, and learning outcomes that they have. Characteristics of students can be distinguished according to the level of education.

The age of elementary school is a mature period for learning, as well as a mature period for the school. Soemantri, Mulyadi, \& Permana [10] explain the characteristics of elementary school students among others:

1) curiosity of students who are strong and interested in the world around;

2) students are more likely to play;

3) like to arrange themselves to handle various things;

4) explore a situation and try new ventures;

5) they are usually thrilled with feelings and are encouraged to achieve as they do not like to experience dissatisfaction and reject failures;

6) they learn effectively when they are satisfied with the situation that occurs;

7) they learn by working, observing, initiating, and teaching other children.

Izzaty [11] divides the final childhood into two phases, namely: 
1) The period of the low-grade elementary school that lasts between the ages of 6/7 years $9 / 10$ years, usually they sit in grades 1,2 , and 3 of elementary school. The characteristics of children in the low class are:

a. physical condition and school achievement have a strong relationship,

b. like to praise yourself,

c. if you cannot complete a task or job, then the task or job is considered not important,

d. like to compare himself with other children, if it benefits him, and

e. likes to belittle others.

2) The period of high school elementary school takes place between the ages of 9/10 years-12/13 years, usually, they sit in grades 4,5 and 6 . The characteristics of high-class children are:

a. his attention is focused on everyday practical life,

b. curious, eager to learn and realistic,

c. interest arises in special lessons,

d. children see value as the right measure of their learning achievement in school, and

e. children like to form peer groups or peer groups to play together, they make their own rules in their groups.
Based on the opinions above elementary school students are more able to accept using concrete objects, student-centered, playing with peer groups. Therefore the internalization of character must be in accordance with the stage of child development.

\section{Result (Internalization of Discipline Charac- ters in SDIT Students)}

This theoretical study originated from high public interest in SDIT. This becomes an interesting thing. Some print media said that this interest was based on several reasons. One of them is planting characters. This character planting is in accordance with Presidential Regulation No. 87 Th 2017 concerning strengthening character education. At SDIT they have carried out character education for a long time. Character education is carried out in the process of internalization in the SDIT environment, which both internalize the characters in the school environment.

The character that is highlighted is discipline. Internalization of the character of this discipline can be done through five stages that are collaborated with character discipline indicators. Internalization of Discipline Characters in SDIT Student, in Fig. 1.
Community interest in SDIT is high because of their good religious knowledge and character

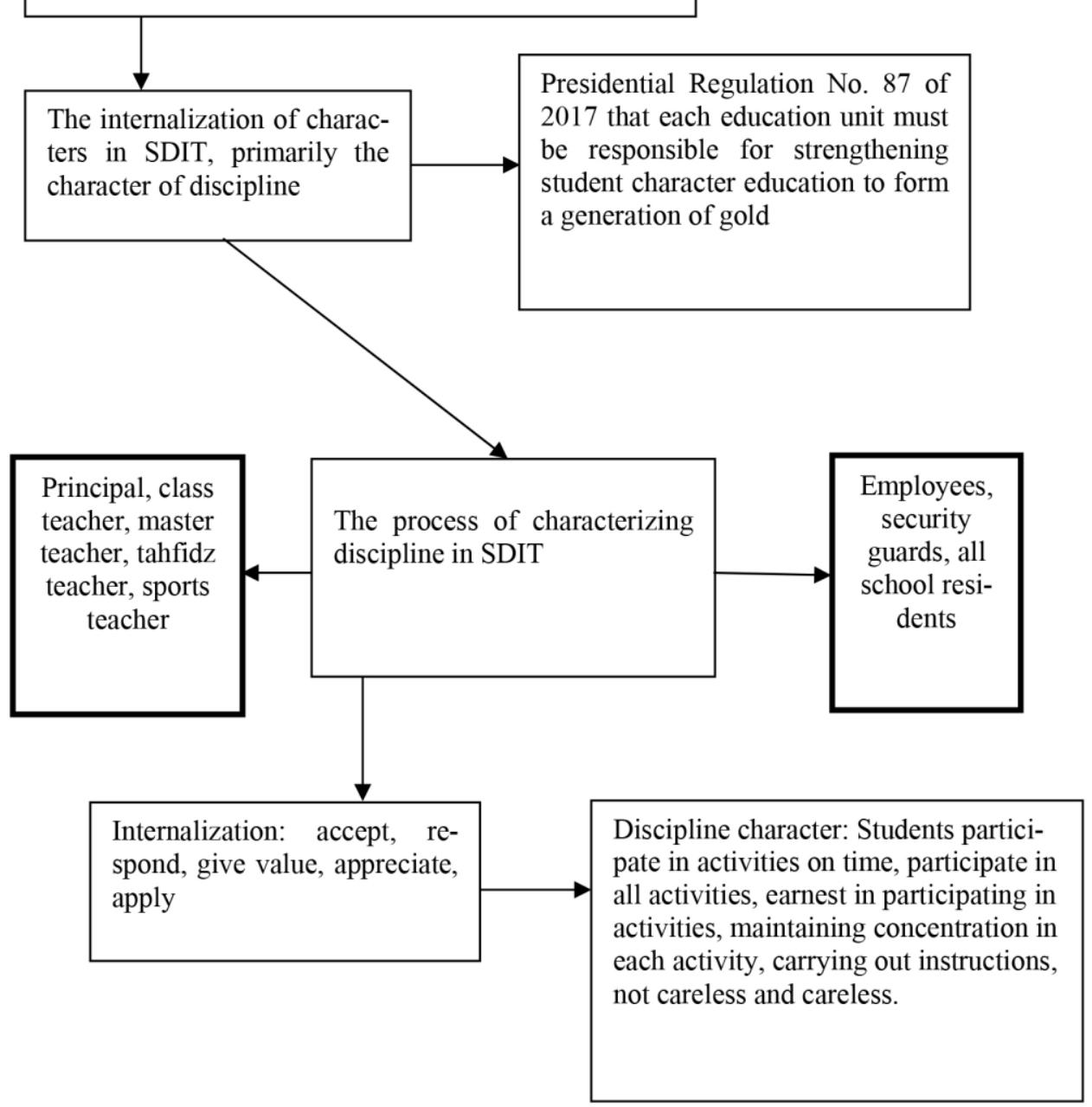

Fig. 1. Internalization of Discipline Characters in SDIT Student 


\section{Conclussion}

Based on the discussion of theoretical studies that have been presented review theoretically:

1) The internalization of the character in students, it is concluded that the process of internalizing the character of discipline in integrated Islamic elementary school students;

2) The process of estlabishing discipline in SDIT students, it is occurs through five stages of the disciplinary characters developed in SDIT students.

\section{References}

1. Wicaksono T. Y., Friawan D. Recent Developments in Higher Education in Indonesia: Issues and challenges. Financing Higher Education and Economic Development in East Asia, 2011. doi: https://doi.org/10.22459/fheedea.11.2011.08

2. Saud U., Johnston M. Cross-cultural influences on teacher education reform: reflections on implementing the integrated curriculum in Indonesia // Journal of Education for Teaching. 2006. Vol. 32, Issue 1. P. 3-20. doi: https://doi.org/10.1080/ 02607470500510894

3. Ali M. E-learning in the Indonesian education system // Asia-Pacific Collaborative education Journal. 2005. Vol. 1, Issue 2. P. 15-24.

4. Yulianto A. Pendidikan Ramah Anak Studi Kasus SDIT Nur Hidayah Surakarta // At-Tarbawi: Jurnal Kajian Kependidikan Islam. 2016. Vol. 1, Issue 2. P. 137. doi: https://doi.org/10.22515/attarbawi.v1i2.192

5. Peraturan Presiden RI Nomor 87, Tahun 2017, tentang Penguatan Pendidikan Karakter. URL: https://bulelengkab.go.id/ assets/instansikab/126/bankdata/peraturan-presiden-ri-nomor-87-tahun-2017-17.pdf

6. Hiroyuki A., Juliawan J., Sudarsana I. K. Internalization Values Of Character Education Towards The Teruna-Daha In The Medi-Median Tradition // Vidyottama Sanatana: International Journal of Hindu Science and Religious Studies. 2018. Vol. 2 , Issue 2. P. 232-238. doi: https://doi.org/10.25078/ijhsrs.v2i2.623 2000.

7. Muhadjir N. Ilmu pendidikan dan perubahan sosial: teori pendidikan pelaku sosial kreatif. Yogyakarta: Teke Sarasin,

8. Curvin R. L., Mindler A. N. Discipline With Dignity. Association For Supervision And Curriculum Development, 1999.

9. Arikunto S. Dasar-dasar evaluasi pendidikan. Jakarta: Bumi Aksara, 2005.

10. Soemantri, Mulyadi dan Permana, J. Strategi Belajar Mengajar. Jakarta: Depdikbud, 1999.

11. Izzaty R. E. Perkembangan peserta didik. Yogyakarta: UNY Press, 2012.

Received date 18.08.2019

Accepted date 12.09.2019

Published date 30.09.2019

Anita, Primary Education, Postgraduate Program, Yogyakarta State University, Colombo str., 1, Karang Malang, Caturtunggal, Depok District, Sleman Regency, Daerah Istimewa Yogyakarta, Indonesia, 55281

E-mail: anita0618pasca2016@student.uny.ac.id

Wuri Wuryandani, Primary Education, Faculty of Education, Yogyakarta State University, Colombo str., 1, Karang Malang, Caturtunggal, Depok District, Sleman Regency, Daerah Istimewa Yogyakarta, Indonesia, 55281 E-mail: wuri_wuryandani@uny.ac.id 